( Валентина Чоп'як, Христина Ліщук-Якимович, Роман Пукаляк, 2020

doi:10.37321/immunology.2020.3-4-04

УДК 616.988.7: 578.834.1] -092.19

\title{
ІМУНОЛОГІЧНІ АСПЕКТИ COVID-2019: РЕАЛIÏ ТА ПЕРСПЕКТИВИ
}

\author{
ВАЛЕНТИНА ЧОП'ЯК, ХРИСТИНА ЛІЩУК-ЯКИМОВИЧ, РОМАН ПУКАЛЯК \\ Кафедра клінічної імунології та алергології, Львівський національний медичний університет \\ імені Данила Галицького, \\ КНП ЛОР «Львівський обласний клінічний діагностичний центр» Львів, Україна
}

Коронавірусна інфекція 2019 (COVID-19) це потенційно тяжка гостра респіраторна інфекція, яка викликається корона вірусом-2 (SARS CoV-2), зумовлюючи розвиток тяжкого гострого респіраторного синдрому (SARS) [1]. Вірус був виявлений в грудні 2019 року. Він спровокував спалах пневмонії невідомої етіології в місті Ухань, провінція Хубей,Китайської народної республіки (КНР). У зразках бронхоальвеолярного лаважу пацієнтів був виявлений раніше невідомий бета-коронавірус. Коронавіруси - це велике сімейство РНК-вірусів, при цьому деякі 3 них викликають захворювання у людей (прояви застуди, тяжкий гострий респіраторний синдром, близькосхідний респіраторний синдром), а інші - циркулюють серед ссавців (кажанів, верблюдів), птахів, плазунів. Більшість пацієнтів з цього спалаху повідомили про зв'язок з великим ринком морепродуктів і живих тварин (Південно-Китайський ринок морепродуктів) в Ухані $[1,2]$. Міжнародний комітет з таксономії вірусів підтвердив назву SARS CoV-2 для найменування цього вірусу, зважаючи на його генетичній схожості з вірусом SARS-CoV (86\%), приймаючи також до уваги те, що між зазначеними вірусами можуть бути відмінності в характеристиках і способах передачі захворювання [1,3]. SARS-CoV-2 відноситься до підроду Sarbecovirus сімейства Coronaviridae i $€$ сьомим відомим коронавірусом, яким може інфікуватися людина. Повний геном вірусу був встановлений і опублікований в GenBank [3]. Всесвітня організація охорони здоров'я (BOO3) підтвердила, що COVID-19 (скорочено від назви «коронавірусна інфекція 2019») є захворюванням, яке викликане інфекцією SARS-CoV-2 [3]. Клінічна картина цього захворювання варіює від легкого грипоподібного стану до тяжкої вірусної пневмонії з ризиком розвитку дистрес-синдрому, міокардиту, ушкодженням травної, нервової, видільної систем [4].

З того часу спалах хвороби швидко набув загрозливих рис, і ВООЗ спочатку оголосила 30 січня 2020 року про надзвичайну ситуацію в КНР, що має міжнародне значення, а потім офіційно - про пандемію 11 березня 2020 року. Спалах хвороби швидко поширився з одного міста в
КНР на всю країну всього за 30 днів, а зараз, на середину квітня 2020 р., охопив 189 країн світу, більше 3 млн. заражених [3,4,5].

Поширення цього вірусу від людини до людини було підтверджено в загальній популяції [4], в установах охорони здоров'я, у домашніх умовах. Передача вірусу серед людей відбувається через дрібні краплі слини, що утворюються при чханні або кашлі. Можливість передачі вірусу через інші біологічні рідини організму невідома; тим не менш, вірус був виявлений в крові, слині, сльозах і секретах кон'юнктиви, крім того можливий фекальний шлях передачі інфекції. Існує все більше свідчень того, що може відбуватися поширення інфекції від безсимптомних носіїв, це спостерігалося в ендемічних районах $[5,6]$. У одному дослідженні безсимптомна передача була зареєстрована в 12,6\% випадків, хоча останні дослідження підвержують, що це біля 30\% [2,7]. Суперпоширювачі можуть передавати інфекцію у великій кількості серед інших людей, з якими вони контактували, включаючи працівників сфери охорони здоров'я. У деяких з цих людей спостерігається супервиділення вірусу, однак причини, що лежать в основі подій, часто є багатофакторними і можуть включати різні поведінкові чинники і фактори навколишнього середовища $[4,8]$.

Найвразливішими виявились люди старшого віку з супутніми захворюваннями: гіпертонія, цукровий діабет, захворювання дихальної системи [9,11-14]. Китайський центр по контролю і профілактиці захворювань опублікував дані досліджень (82 314 випадків з 31 грудня 2019 року по 21 лютого 2020 року). Більшість підтверджених випадків (95\%) зафіксовані серед пацієнтів 20-79 років, 1\% випадків - це пацієнти 9 років і молодше, 1\% - 10-19 років і 3\% - у віці 80 років і старше. Приблизно 51\% хворих - чоловіки і 49\% - жінки. Майже 29\% випадків припадало на працівників сфери охорони здоров'я. У одному дослідженні повідомлялося про нозокоміальну передачу інфекції у працівників охорони здоров'я від пацієнтів, яка була зареєстрована у $41 \%$ випадків $[3,15,16]$.

США нині займає першість серед уражених на COVID 19 - більше 900 000: літні пацієнти (ві- 
ком $\geq 65$ років) становлять 31\% всіх випадків, серед них - 45\% госпіталізацій, 53\% госпіталізації у відділеннях інтенсивної терапії та 80\% випадків смерті у цій віковій групі, причому найвища частота тяжких випадків спостерігалася у пацієнтів у віці $\geq 85$ років

Згідно з даними ВООЗ, тривалість інкубаційного періоду варіює від 1 до 14 днів. Середній інкубаційний період, за оцінками, становить приблизно 5 днів. Передача інфекції цілком можлива під час інкубаційного періоду, а також 8-39 днів після одужання. Попередні звіти припускають, що репродуктивне число (R0), тобто кількість людей, що заражаються інфекцією від інфікованої людини, становить приблизно 3,2. Однак, оскільки ситуація все ще розвивається, фактичний показник RO може бути вище. Показник вторинного зараження при SARS-CoV-2 оцінюється в 0,45\% при близьких контактах з пацієнтами [17-19].

Хоча в даний час патофізіологія цього захворювання невідома, припускають, що вірус зв'язується з рецептором ангіотензинперетворюючого ферменту-2 (ACE2) у людей, що дозволяє припустити наявність патогенезу, схожого з SARS. Однак унікальна структурна особливість рецептор-зв'язуючого домену глікопротеїну шиповидних відростків SARS-CoV-2 (який відповідає за проникнення вірусу в клітини господаря) забезпечує потенційно більш високу афінність зв'язування для ACE2 з клітинами-господарями в порівнянні з SARS-CoV. У шиповидному білку вірусу було ідентифіковано місце розщеплення його фуриноподібною речовиною, чого не спостерігається для інших SARS-подібних корона вірусів [3,20].

Виходячи з аналізу наборів даних секвенування РНК з однієї клітини, отриманих з основних фізіологічних середовищ людини, більш ураженими інфекцією SARS-CoV-2 органами, через рівні експресії АПФ2 на клітинах, вважаються легені, серце, стравохід, нирки, сечовий міхур, клубова кишка, нейрони. Високі вірусні навантаження були виявлені в мазках з носа i глотки незабаром після появи симптомів, і вважається, що характер виділення вірусу може бути аналогічний такому в пацієнтів з грипом. Виявлено, що безсимптомний пацієнт має аналогічне вірусне навантаження в порівнянні з пацієнтами, у яких симптоми спостерігаються.

Основні захисні процеси від цього вірусу, як і від інших, забезпечує імунна система. Вона мобілізується і відповідає своїм вродженим і набутим імунітетом та намагається захистити і включити свої механізмами для того, щоб цей збудник був зупинений. У першу чергу, з природженого імунітету активно задіюються 5 основних рецепторів на мембранах епітеліальних та ендотеліальних клітин, завдання яких активізувати клітини природженого імунітету, забезпечити продукцію інтерферонів та інших прозапальних факторів цитокінового характеру, щоб захистити наш організм від цього збудника $[11,12]$. Це осовні сімейства TLR- рецепторів, RIG-рецепторів, NOD-рецепторів, CLRрецепторів, CDR-рецепторів, які мобілізованою армією намагаються розібратися з даним збудником на рівні мембран та цитоплазми, Вони в подальшому, через сигнальні системи, забезпечать активацію клітин природженої та й набутої імунної системи, щоб були спродуковані інтерферони та інші прозапальні цитокіни, активізувались імунні клітини адаптивного імунітету на специфічну боротьбу з даним збудником. Крім того, активно приймають участь запальні моноцити CD14+, CD16+ з високою продукцією цитокінів та нейтрофіли [19,20].

У цій ситуації ми маємо виклик, коли коронавірус не дає активно включитися природному імунітету, що веде до низької інтерферонопродукції. У зв'язку з цим функція дендритичних клітин, які є прекрасними антигенпрезентуючими клітинами, блокується, що в перші дні не дає активізуватись клітинам адаптивного імунітету і продукувати достатньо відповідних цитокінів, як стимулюючих, так і гальмуючих. Тобто, забезпечити регуляторну відповідь нашої імунної системи на вірусний виклик. В умовах депресії імунна система починає надпотужно активуватися і через певний період наступає її значна гіперактивація, що веде до системного запального процесу $[21,23]$.

Звичайно, в природженому імунітеті, крім цитокінових механізмів, також включаються до противірусного захисту і інші гуморальні фактори: система моноцитів-макрофагів, система комплементу, система дефенсинів, система коліцинів тощо.

Тут ми показуємо, що після проникнення інфекції SARS-CoV-2 в організм людини та обробки її природженими клітинними та гуморальними факторами захисту включаються клітини адаптивного (набутого) імунітету - лімфоцити CD4+ Т-хелпери (Th) швидко активуються, стаючи високоактивними патогенними Т-хелперами Th1 та Th17. Відомо, що велика кількість інфільтрацій запальних лімфоцитів спостерігалась в легенях, особливо Т-цитотоксичних (Tc) - CD8+ у тяжких пацієнтів із COVID-19. Крім того, аберрантні патогенні клітини Th1,Th17 та запальні моноцити можуть надходити у легеневий кровообіг у величезній кількості, спричиняючи значне функціональне пошкодження легень та швидку смертність на основі агресивного імунного запалення [22, 24-26]. Для демонстрації статусу цих аберрантно змінених Т-хелперів було проаналізовано кілька лімфоїдних активізаційних антигенів. Ці CD4+ Т-клітини у пацієнтів із 
COVID-19 мають більш високу експресію CD69, CD38 та CD44 порівняно зі здоровими контрольними групами, що вказує на їх активований статус. Повідомлялося, що ОХ40 відіграє головну роль у сприянні клональної експансії та індукції вироблення декількох цитокінів Т-хеплерами. У пацієнтів із COVID-19 експресія OX40 помітно в них зросла, особливо у тяжких хворих. Клітини CD8+T у пацієнтів із COVID-19 також демонстрували активований фенотип із підвищеною експресією CD69, CD38 та CD44. Костимулююча молекула 41BB (CD137; TNFRS9), індукована активацією, важлива для імунних реакцій цитотоксичними клітинами CD8+ T. У пацієнтів, які перебували у стаціонарних відділеннях, інфікованих SARS-CoV-2, експресія 41BB значно зростала порівняно зі здоровими контрольними групами. Повідомлялося, що спільна експресія Tim-3 та PD-1 можуть бути субпопуляцією Т-клітин із сильнішим виснаженням за умови вірусних інфекцій. Варто зазначити, що значно більший відсоток співекспресії Tim3+ PD-1 виявлена, як у CD4+, так і у CD8+ Т-клітинах у пацієнтів із COVID-19, порівняно з іншими некороновірусними пневноніями $[25,26]$.

Про участь В-лімфоцитів у COVID-19 свідчить вироблення специфічних антитіл. Нині виявлено більше 30 видів моноклональних антитіл до різних видів білків, які сконцентровані на поверхні самого віруса і всередині нього. Ідентифіковано дуже потужне антитіло, яке, власне, працює 3 рецептором ангіотензинперетворюючого ферменту; це моноклональне антитіло-336, яке, в перспективі, може складати і серйозну терапевтичну допомогу, оскільки, блокуючи цей рецептор, вірус не зможе входити в клітини-мішені [26].

Хоча вірусне ухилення від імунних реакцій господаря та спричинений вірусом цитопатичний вплив являються критичними за тяжкості захворювання. Встановлено, що надмірний і некерований цитокіновий шторм господаря призводить до бурхливої імунопатології та летального наслідку хвороби. Шторм цитокінів може розпочатися на одному локальному місці, але далі поширитися в організмі через кровообіг і зумовити системний запальний синдром. Так, у пацієнтів, інфікованих SARS-CoV-2, були виявлені підвищені плазмові концентрації цитокінів: інтерлейкінів (IL) 1, 2, 6, 7, 8, 12, 17, 23, колонієстимулюючого фактору моноцитів-гранулоцитів та гранулоцитів (MG- CSF та G-CSF ), індукованого інтерфероном -білка 10 (IP10), моноцитного хемоатрактантного протеїну- 1 (МСР-1), макрофагального запального білка 1- (MIP1-), фактору некрозу пухлини- (TNF-), високий рівень інтерферону- (IFN), трансформуючий фактор росту- (TGF), CCL2, CXCL10 та CXCL9. Однак, на відміну від пацієнтів, інфіко- ваних SARS-CoV-2, низький рівень IL-10 та високий рівень IL-1 $\beta$ часто виявляли у SARS-CoV $[27,28,31]$.

Гіперпродукція цитокінів, які спостерігаються у пацієнтів із тяжким перебігом COVID-19, демонструють схожість із тими, що спостерігаються у пацієнтів із синдромом активації макрофагів, на тлі якого включаються неконтрольовані запальні механізми в макроорганізмі [30,31].

Аналогічний перебіг захворювання, який спостерігається під час інфекції SARS-CoV-2, був описаний під час інфікування іншими високопатогенними коронавірусами, такими як SARS-CoV та MERS-CoV з летальним завершенням у $20 \%$ пацієнтів. У цих хворих спостерігалась виражена клітинна інфільтрація макрофагами в легенях.

Зараз $є$ цікаві роботи у японських, американських, французьких вчених, які звернули увагу на інтерфероніндукуючий протеїн - хемокін 10, - який у великій кількості продукується у пацієнтів з тяжким перебігом COVID-19. Він продукується багатьма клітинами природженого імунітету і є потужним блокатором як природженого імунітету, так і набутого [31].

У пацієнтів, інфікованих SARS-CoV, повідомлялося, що ступінь тяжкості ураження легень корелює зі збільшенням кількості нейтрофілів та моноцитів у периферичній крові та зниження кількості CD8+ та CD4+ Т-клітин. Кількість загальних лейкоцитів у периферичній крові не мала суттєвих відмінностей між пацієнтами COVID-19 та здоровими контрольними групами, тоді як кількість лімфоцитів значно зменшувалась у пацієнтів, які лікувались в стаціонарі. У той же час, кількість моноцитів була підвищена. Кількість Т-клітин зменшувалась і у пацієнтів у стаціонарі та в амбулаторних умовах, за рахунок, в основному, CD4+ Т-клітин, тоді як CD8+ Т-клітини значно зменшувалися лише у хворих у реанімаційних відділеннях. Інші види лейкоцитів, включаючи гранулоцити, В-клітини та NKклітини, не були суттєво змінені кількісно у пацієнтів з COVID-19 та здорових контрольних груп $[32,33]$.

щодо клінічних моментів, ми зараз маємо 4 варіанти імунної відповіді на контакт з цим збудником [21,34]. Ми маємо 30\% носіїв - люди 3 хорошою імунною системою, які не мають клініки та успішно переносять збудник і цим самим створюють високу поширеність. У цьому значна небезпечність цього вірусу. Другий варіант - це 55\% популяції, коли ми маємо легкі форми перебігу COVID-19. Отже, в сумі, 85\% популяції дають адекватну хорошу імунну відповідь, добру організацію імунної системи. Тому, такий респіраторний стан часто пацієнти та й лікарі плутають 3 легкою формою грипу, а в дійсності - це COVID-19. I знову проявляється підступність 
цього вірусу, бо після одужання легких форм, від 10 до 40 днів є подальше виділення вірусу, що створює моменти зараження оточуючих.

Проте, 15\% мають дуже серйозні виклики та роздуми для клініцистів та фахівців з епідеміології, імунології, вірусології, молекулярних генетиків та інших фахівців, які серйозно думають, яким чином можна зупинити агресивний некерований варіант перебігу COVID-19, з яким зустрілось людство. Щодо середньо-тяжкої та тяжкої форм, то ми маємо прояви пневмонії, міокардиту і серйозні ушкодження нервової, травної, видільної систем. 3 огляду імунної системи, спостерігається стадійність: спочатку незначна активація імунної системи (1-ша доба), швидкий розвиток імунодефіциту (2-7 доба), коли в загальному аналізі крові падає кількість лімфоцитів. Після цієї фази, приблизно на 7-14 добу, йде активна мобілізація імунної системи на тлі імунодефіциту і в цей період дуже часто приєднується бактеріальна інфекція, яка активно ушкоджує нижні відділи дихальних шляхів, розвиваючи вірусно-бактеріальну пневмонію. Але, у цей же час надпотужно активована імунна система, дякуючи хелперним мобілізаціям, особливо хелперів 17 типу, які посилюють продукцію інтерлейкіну 6 - ключового цитокіну в формуванні системного запального процесу. За цих умов намагаються включитися регуляторні механізми для того, щоб зупинити таку агресивність імунної системи, але безуспішно. Тому пневмонія набуває не тільки вірусно-бактеріального характеру, але й аутоімунного. Розвиваються тяжкі альвеоліти, інтерстиціальні ушкодження сполучної тканини легень [23,31,34].

Четвертий варіант - це незначна активація із вираженим глибоким дефіцитом імунної системи з гіперімунною відповіддю та включенням потужних запальних процесів та розвитком дистрес-синдрому. У клініці маємо панцитопенічний синдром, наростання ферритину, гіперактивації системи коагуляції з виявленням димерів, тяжку лімфопенію з гострою дихальною недостатністю. Таких пацієнтів треба підключати до апарату штучного дихання. Високого ефекту від штучної вентиляції легень не можна відмітити, про це повідомляють у США, Франції та Італії. У тій ситуації використовують моноклональні антитіла, інгібітори рецептору інтерлейкіну 6 (Тоцилізумаб), рецептора інтерлейкіну 1 (Анакінра), гіперімунну реконвалісцентну плазму, але поки переконливих доказових досліджень про високу ефективність немає, результат коливається від 27 до 35\% ефекту від такої потужної імуномодулюючої терапії у цих 15\% хворих. Поки ми не маємо доказових ефективних специфічних противірусних ліків та вакцин, які б цільово працювали і врегулювали нам імунну відповідь в цій ситуації $[27,34]$.
На даний час існує декілька теорій розвитку тяжких форм COVID-19: вірусно-бактеріальна, геномна, мікроцикуляторна. Усі вони пов'язані з імунними порушеннями в розвитку COVID-19 [33,34,35]. Вірусно-бактеріальна викладена вище. Геномна доводить, що поверхневі (мембранні) білки ORF8 та глікопротеїн можуть зв'язуватися з порфіринами, а цитоплазматичні білки orf1ab, ORF10, ORF3a можуть координувати атаку гема в бета-ланцюгу гемоглобіну, що призводить до витіснення заліза і утворення вільної молекули порфирину, що спричиняє зниження кількості гемоглобіну, здатного переносити кисень і діоксид вуглецю. Клітини легень реагують на зміну газообміну посиленням запалення - так виникає ефект «матового скла», який діагностується за допомогою комп'ютерної томографії. Цей токсичний запальний процес в легеневій тканині в тяжких випадках, наростаючи лавиноподібно, перетворюється в цитокіновий шторм. Ця найсильніша системна реакція, що виникає в результаті гіперактивації імунної системи, призводить до руйнування легеневої тканини, порушень в роботі серцево-судинної системи, печінки, нирок і навіть головного мозку. Якщо ця гіпотеза експериментально підтвердиться, стане зрозумілим терапевтичний ефект протималярійних препаратів з імуносупресивною дією. Вчені показали, що препарат хлорохін та гідроксихлорахін, які вбивають збудників малярії, що живуть в еритроцитах, можуть запобігати атаці коронавірусних білків на гем. А противірусний препарат фавіпіравір здатний не тільки запобігти проникненню вірусу в клітину, а й пригнічувати зв'язування вірусних білків 3 порфірином. Ця гіпотеза посилюється стійкістю до захворювання дітей першого року життя, в крові яких переважає фетальний гемоглобін без бета-ланцюгів і, ймовірно, невразливий для вірусних білків. Гемоглобін без бета-ланцюгів синтезується і у хворих таласемією, генетичним захворюванням, поширеним в «малярійних» районах Африки - в цих країнах відзначена невисока захворюваність на COVID-19 [28,32].

Мікроциркуляторна теорія характеризується високою експресією АCE2, в першу чергу, на ендотеліальних клітинах мікроциркуляторного русла і після проникнення вірусу в клітини ендотелію, що зумовлює розвиток тяжких «малих» васкулітів. Ці процеси теж зводяться до системного імунного запалення з розвитком цитокінового шторму і пошкодженням життєвоважливих органів та систем. Перспективним, виходячи з цієї теорії, в лікуванні легких форм захворювання COVID-19 та його профілактики могло б бути застосування інгібіторів ангіотензин-перетворюючого ферменту, сартанів - блокато- 
рів рецепторів ACE2, антиоксидантів тощо. Але все це припущення, які потребують доказових експериментальних та клінічних досліджень [33,34,35].

Така ситуація потребує більш серйозних та глибоких генетичних, імунологічних аналізів великої когорти об'єктів. Можливо, є певна генетична та епігенетична схильность до такої надактивної імунної відповіді, а також до кінця не ясні вікові виклики, потребують аналізу супутні патології, необхідність профілактичних заходів, в першу чергу, дієвої вакцини до SARS-CoV2. Захворювання має багатофазний характер, вторинна цитокінова буря призводить до летальних наслідків. На ранніх стадіях захворювання лікування має бути зосереджене на зниженні вірусного навантаження або специфічними противірусними препаратами, або стимулюючим ІФН типу І. На більш пізніх стадіях терапія має бути спрямована на прозапальні цитокіни, для інгібування надмірного запалення, поряд з тим, деякі цитокіни (IL-7) теоретично могли сприяти відновленню імунної відповіді. У клінічній практиці, на жаль, не виявляються пацієнти на ранній стадії COVID-19 (тобто до настання симптомів), щоб отримати позитивний результат від противірусної терапії. На сьогоднійшній день, маркери, які прогнозують варіант перебігу COVID-19, $€$ найбільш необхідними і очікуваними.

Отже, для лікарів імунологів багато завдань: визначення специфічних і чутливих маркерів до розвитку тяжких форм COVID-19, зупинка цитокіного шторму із застосуванням протизапальних або імунорегулюючих моноклональних антитіл, реконвалісцентної плазми, гіперімунних специфічних імуноглобулінів, після перенесення легких і середньо-важких форм SARS-CoV2 визначення біомаркерів прогнозування фіброзу легень, малих васкулітів, ефективна вакцинація до SARS-CoV2, особливо у імунокомпроментованих осіб, формування колективного імунітету до цієї інфекції.

\section{ЛITEPATУPA}

1. Coronaviridae Study Group of the International Committee on Taxonomy of Viruses. The species severe acute respiratory syndrome-related coronavirus: classifying 2019-nCoV and naming it SARS-CoV-2. Nat Microbiol. 2020 Apr;5(4):536-44.

2. Ren $L L$, Wang $Y M, W u Z Q$, et al. Identification of a novel coronavirus causing severe pneumonia in human: a descriptive study. Chin Med $J$ (Engl). 2020 Jan 30 [Epub ahead of print].

3. World Health Organization. Clinical management of severe acute respiratory infection (SARI) when COVID-19 disease is suspected. 2020 [internet publication].
4. Lauer SA, Grantz KH, Bi Q, et al. The incubation period of coronavirus disease 2019 (COVID-19) from publicly reported confirmed cases: estimation and application. Ann Intern Med. 2020 Mar 10 [Epub ahead of print].

5. Huang $C$, Wang $Y, L i X$, et al. Clinical features of patients infected with 2019 novel coronavirus in Wuhan, China. Lancet. 2020 Feb 15;395(10223):497-506.

6. Chen N, Zhou M, Dong X, etal. Epidemiological and clinical characteristics of 99 cases of 2019 novel coronavirus pneumonia in Wuhan, China: a descriptive study. Lancet. 2020 Feb 15;395(10223):507-13.

7. Li Q, Guan $X, W u P$, et al. Early transmission dynamics in Wuhan, China, of novel coronavirus-infected pneumonia. N Engl J Med. 2020 Mar 26;382(13):1199-207.

8. Paraskevis D, Kostaki EG, Magiorkinis G, et al. Full-genome evolutionary analysis of the novel corona virus (2019-nCoV) rejects the hypothesis of emergence as a result of a recent recombination event. Infect Genet Evol. 2020 Jan 29; 79:104212.

9. Lam TT, Shum MH, Zhu HC, et al. Identifying SARS-CoV-2 related coronaviruses in Malayan pangolins. Nature. 2020 Mar 26 [Epub ahead of print].

10. Chan JF, Yuan S, Kok KH, et al. A familial cluster of pneumonia associated with the 2019 novel coronavirus indicating person-to-person transmission: a study of a family cluster. Lancet. 2020 Feb 15;395(10223):514-23.

11. World Health Organization. Modes of transmission of virus causing COVID-19: implications for IPC precaution recommendations. 2020 [internet publication].

12. Zhang $H$, Kang $Z$, Gong $H$, et al. The digestive system is a potential route of 2019-nCov infection: a bioinformatics analysis based on single-cell transcriptomes. 2020 [internet publication].

13. Zhang $W, D u R H, L i B$, et al. Molecular and serological investigation of 2019-nCoV infected patients: implication of multiple shedding routes. Emerg Microbes Infect. 2020 Dec;9(1):386-9.

14. To KK, Tsang OT, Chik-Yan Yip C, et al. Consistent detection of 2019 novel coronavirus in saliva. Clin Infect Dis. 2020 Feb 12 [Epub ahead of print].

15. Xia J, Tong J, Liu M, et al. Evaluation of coronavirus in tears and conjunctival secretions of patients with SARS-CoV-2 infection. J Med Virol. 2020 Feb 26 [Epub ahead of print]. 
16. Centre for Evidence-Based Medicine; Ferner RE, Murray PI, Aronson JK. Spreading SARSCoV-2 through ocular fluids. 2020 [internet publication].

17. Sun T, Guan J. Novel coronavirus and central nervous system. Eur J Neurol. 2020 Mar 26 [Epub ahead of print].

18. World Health Organization. Novel coronavirus (2019-nCoV) situation report - 6. 2020 [internet publication].

19. Centers for Disease Control and Prevention. Coronavirus disease 2019 (COVID-19): symptoms of coronavirus. 2020 [internet publication].

20. Huang $C$, Wang $Y$, Li X, Ren L, Zhao J, Hu Y, et al. Clinical features of patients infected with 2019 novel coronavirus in Wuhan, China. Lancet 2020.

21. Yu P, Zhu J, Zhang Z, et al. A familial cluster of infection associated with the 2019 novel coronavirus indicating potential personto-person transmission during the incubation period. J Infect Dis. 2020 Feb 18 [Epub ahead of print].

22. $D u Z, X u X, W u Y$, et al. Serial interval of COVID-19 among publicly reported confirmed cases. Emerg Infect Dis. 2020 Mar 19;26(6).

23. Wei WE, Li Z, Chiew CJ, et al. Presymptomatic transmission of SARS-CoV-2: Singapore, January 23 - March 16, 2020. MMWR Morb Mortal Wkly Rep. 2020 Apr 1 [Epub ahead of print].

24. Rothe $C$, Schunk $M$, Sothmann $P$, et al. Transmission of 2019-nCoV infection from an asymptomatic contact in Germany. N Engl J Med. 2020 Mar 5;382(10):970-71.

25. Kupferschmidt $K$. Study claiming new coronavirus can be transmitted by people without symptoms was flawed. 2020 [internet publication].

26. Baruah V, Bose S. Immunoinformatics-aided identification of $T$ cell and $B$ cell epitopes in the surface glycoprotein of 2019-nCoV. J Med Virol. 2020;92(5):495-500. doi:10.1002/ jmv.25698

27. Hu Z, Song $C, X u C$, et al. Clinical characteristics of 24 asymptomatic infections with COVID-19 screened among close contacts in Nanjing, China. Sci China Life Sci. 2020 Mar 4 [Epub ahead of print].

28. Xu Z, Shi L, Wang $Y$, Zhang J, Huang L, Zhang $C$, et al. Pathological findings of COVID-19 associated with acute respiratory distress syndrome. The Lancet Respiratory Medicine.

29. Rockx B, Baas T, Zornetzer GA, Haagmans B, Sheahan T, Frieman $M$, et al. Early upregula- tion of acute respiratory distress syndromeassociated cytokines promotes lethal disease in an aged-mouse model of severe acute respiratory syndrome coronavirus infection. J Virol 2009, 83(14): 7062-7074.

30. Tisoncik JR, Korth MJ, Simmons CP, Farrar J, Martin TR, Katze MG. Into the eye of the cytokine storm. Microbiology and molecular biology reviews : MMBR 2012, 76(1): 16-32.

31. Wong, C. K., Lam, C. W. K., Wu, A. K. L., Ip, W. K., Lee, N. L. S., Chan, I. H. S., Lit, L. C. W., Hui, D. S. C., Chan, M. H. M., Chung, S. S. C., \& Sung, J. J. Y. (2004). Plasma inflammatory cytokines and chemokines in severe acute respiratory syndrome. Clinical and Experimental Immunology, 136(1). https:// doi.org/10.1111/j.1365-2249.2004.02415.x

32. Channappanavar R, Perlman S. Pathogenic human coronavirus infections: causes and consequences of cytokine storm and immunopathology. Semin Immunopathol 2017, 39(5): 529-539.

33. Andersen, K.G., Rambaut, A., Lipkin, W.I. et al. The proximal origin of SARS-CoV-2. Nat Med 26, 450-452 (2020). doi.org/10.1038/ s41591-020-0820-9

34. Li G, Fan Y, Lai Y, Han T, Li Z, Zhou P, et al. Coronavirus infections and immune responses. J Med Virol 2020.

35. Colantuoni A, Martini R, Caprari P, Ballestri $M$, Capecchi PL, Gnasso A, Lo Presti R, Marcoccia A, Rossi $M$ and Caimi G (2020) COVID-19 Sepsis and Microcirculation Dysfunction. Front. Physiol. 11:747. doi: 10.3389/fphys.2020.00747

\section{PEЗ ЮME}

\section{ІМУНОЛОГІЧНІ АСПЕКТИ COVID-2019: РЕАЛIÏ ТА ПЕРСПЕКТИВИ}

Валентина Чоп'як, Христина Ліщук-Якимович, Роман Пукаляк

Кафедра клінічної імунології та алергології, Львівський національний медичний університет імені Данила Галицького,

КНП ЛОР «Львівський обласний клінічний діагностичний центр» Львів, Україна

Коронавірусна інфекція 2019 (COVID-19) - це тяжка гостра респіраторна інфекція, яка викликається PHК-вмісним коронавірусом-2 (SARS CoV-2), зумовлюючи розвиток тяжкого гострого респіраторного синдрому (SARS). Клінічна картина цього захворювання варіює від легкого грипоподібного стану, до тяжкої вірусної пневмонії з ризиком розвитку дистрес-синдрому, міокардиту, ушкодженням травної, нервової, видільної систем. Згідно з даними ВООЗ тривалість інкубаційного періоду коливається від 1 до 14 днів. Дослідники виділяють чотири варіанти імун- 
ної відповіді при коронавірусній інфекції. Перший варіант - носії вірусу, а це $30 \%$ осіб з активною імунною системою, в яких клінічні прояви відсутні, збільшують кількість інфікованих осіб у загальній популяції.

Другий варіант - це 55\% популяції з легким перебігом COVID-19. Отже, загалом, 85\% населення дають адекватну імунну відповідь. Третій варіант - 10\% хворих з середньо-тяжким перебігом COVID-19 з можливими проявами пневмонії, міокардиту, ушкодженням нервової, травної та видільної систем. Четвертий варіант - здебільшого при тяжкому перебігу COVID-19, спостерігаються виражені порушення імунної системи з гіперімунною відповіддю із залученими потужними запальними процесами та розвитком дистрес-синдрому. Швидке поширення COVID-19 вказує на необхідність ретельної диференційної діагностики з ГРВІ та грипом та термінового пошуку ефективних методів лікування, в першу чергу тяжких форм. Запитань багато, а роботи ще більше, особливо у науковців і лікарів, задля збереження життя людей. Необхідно запровадити мультидисциплінарний підхід з моніторингом імунної відповіді пацієнтів.

Ключові слова: SARS Cov-2, цитокіни, Т-лімфоцити, В-лімфоцити, імунологічні аспекти.

\section{PЕЗЮME}

\section{Иммунологические аспекты COVID-2019: реалии и перспективы}

Валентина Чопяк, Кристина Лищук-Якимович, Роман Пукаляк

Кафедра клинической иммунологии и аллергологии, Львовский национальный медицинский университет имени Данила Галицкого, Украина

КНП ЛОР «Львовский областной клинический диагностический центр» Львов, Украина

Коронавирусная инфекция (COVID-19) - это потенциально тяжелая острая респираторная инфекция, вызываемая РНК-содержащим коронавирусом-2 (SARS CoV-2), и может протекать в виде тяжелого острого респираторного синдрома (SARS). Клиническая картина этого заболевания варьирует от легкого гриппоподобного состояния к тяжелой вирусной пневмонии с риском развития дистресссиндрома, миокардита, повреждением пищеварительной, нервной, выделительной систем. Согласно данным ВООЗ продолжительность инкубационного периода колеблется от 1 до 14 дней. Исследователи выделяют четыре варианта иммунного ответа при коронавирусной инфекции. Первый вариант - носители вируса, а это $30 \%$ лиц с активной иммунной системой, у которых клинические проявления отсутствуют, увеличивают количество инфицированных в общей популяции

Второй вариант - это 55\% популяции с легким течением COVID-19. Итак, в целом, 85\% населения имеют адекватный иммунный ответ. Третий вариант 10\% больных со средне-тяжелым течением COVID-19 с возможными проявлениями пневмонии, миокардита, повреждения нервной, пищеварительной и выделительной систем. Четвертый вариант - в основном при тяжелом течении COVID-19, наблюдаются выраженные нарушения иммунной системы с гипе- риммунным ответом с вовлечением мощных воспалительных процессов и развитием дистресс-синдрома. Быстрое распространение COVID-19 указывает на необходимость тщательной дифференциальной диагностики с ОРВИ и гриппом, а также поиска эффективных методов лечения, в первую очередь тяжелых форм. Вопросов много, а работы еще больше, особенно у ученых и врачей, для сохранения жизни людей. Необходимо ввести мультидисциплинарный подход с мониторингом иммунного ответа пациентов.

Ключевые слова: SARS Cov-2, цитокины, Т-лимфоциты, В-лимфоциты, иммунологические аспекты.

\section{SUMMARY}

IMMUNOLOGICAL ASPECTS OF COVID-2019: REALITIES AND PROSPECTS

Valentyna Chopyak, Khrystyna Lishchuk-Yakymovych, Roman Pukalyak

Department of Clinical Immunology and Allergology, Danylo Halytskyi National Medical University

Municipal Non-Commercial Enterprise of Lviv Regional Council «Lviv Regional Clinical Diagnostic Center» Lviv, Ukraine

Coronavirus infection 2019 (COVID-19) is a severe acute respiratory infection caused by RNA coronavirus-2 (SARS CoV-2), provoced the development of severe acute respiratory syndrome (SARS).

The clinical picture of this disease varies from a mild flu-like condition to severe viral pneumonia with a risk for developing of distress syndrome, myocarditis, damage to the digestive, nervous and excretory systems. According to the $\mathrm{WHO}$, the incubation period ranges from 1 to 14 days. The researchers found four variants of the immune response to coronavirus infection. The first variant - it is $30 \%$ of people with an active immune response and asymptomatic carriage in COVID-19 transmission that increase the number of SARS-Cov-2 infected people in the general population.

The second variant is $55 \%$ of the population with mild COVID19 symptoms. Thus, in general, $85 \%$ of the population have an adequate immune response. The third variant - there are $10 \%$ of patients with moderate to severe COVID-19 signs with possible manifestations of pneumonia, myocarditis, damage to the nervous, digestive and excretory systems. The fourth variant is typical for patients with severe manifestation of COVID-19 and pronounced disorders of the immune system with a hyperimmune response with strong inflammatory processes and the development of distress syndrome. The rapid spread of COVID-19 highlights the need for careful differential diagnosis with SARS, influenza and observe the need for urgent development of effective treatment, especially for severe COID-19. There are many questions, and even more work, especially for scientists and doctors, to save patients live. It should be introduced a multidisciplinary approach to the monitoring of patients' immune responses.

Key words: SARS Cov-2, cytokines, T-lymphocytes, B-lymphocytes, immunological aspects. 
- Чоп'як Валентина Володимирівна доктор медичних наук, професор, завідувач кафедри клінічної імунології та алергології

Львівський національний медичний університет ім. Данила Галицького,

м. Львів, Україна 79000

тел.: (032) 2376142

E-mail: chopyakv@ukr.net

\section{- Ліщук-Якимович Христина} Олександрівна

кандидат медичних наук, доцент, Львівський національний медичний університет ім. Данила Галицького, м. Львів, Україна 79000 Моб. телефон: +380671512468

E-mail: k_yakymovych@ukr.net

\section{- Пукаляк Роман Михайлович} кандидат медичних наук, асистент, Львівський національний медичний університет ім. Данила Галицького,

м. Львів, Україна 79000

Моб. телефон: +380677153318

E-mail: rpukaljak@gmail.com

\section{АВТОРСЬКА ДОВІДКА:}

- Чопяк Валентина Владимировна доктор медицинских наук, профессор, заведующая кафедрой клинической иммунологии и аллергологии

Львовский национальный медицинский университет им. Данила Галицкого,

м. Львов, Украина

тел.: (032) 2376142

E-mail: chopyakv@ukr.net

\section{- Лищук-Якимович Кристина} Александровна

кандидат медицинских наук, доцент, Львовский национальный медицинский университет им. Даниила Галицкого, г. Львов, Украина

Моб. телефон: +380671512468

E-mail: k_yakymovych@ukr.net

\section{- Пукаляк Роман Михайлович} кандидат медицинских наук, ассистент, Львовский национальный медицинский университет им. Даниила Галицкого,

г. Львов, Украина

Моб. телефон: +380677153318

E-mail: rpukaljak@gmail.com
- Chopyak Valentna Volodymyrivna doctor of medical sciences, professor, Head of the Department of Clinical Immunology and Allergology Lviv National Medical University named after Danylo Halytsky,

Lviv, Ukraine

tel.: (032) 2376142

E-mail: chopyakv@ukr.net

\section{- Lishchuk-Yakymovych Khrystyna} Olexandrivna

Candidate of Medical Sciences, Associate Professor,

Lviv National Medical University Danylo Halytsky, Lviv, Ukraine

Mob.tel.: +380671512468

E-mail: k_yakymovych@ukr.net

\section{- Pukalyak Roman Mykhailovych} candidate of medical sciences, assistant, Lviv National Medical University. Danylo Halytsky,

Lviv, Ukraine

Mob.tel.: +380677153318

E-mail: rpukaljak@gmail.com 